\title{
Assessment of Anti-Cancerous Effect of Green, Roasted and Decaffeinated Coffee on Oral Squamous Cell Carcinoma Cell Line (In Vitro Study)
}

\author{
Asmaa E. E. M. Rashad ${ }^{*}$, Mohsen K. Abdel Latif and Manar A. Abdul-Aziz \\ Oral and Maxillofacial Pathology, Faculty of Dentistry, Cairo University, 12613, Egypt; \\ asmaa.rashad@dentistry.cu.edu.eg,m.kazem@dentistry.cu.edu.eg,M.waniss@yahoo.com
}

\begin{abstract}
Oral Squamous Cell Carcinoma (OSCC) is one of the most prevailing malignancies of the head and neck area. So far, treatment methods are associated with harmful effects which drive attention towards natural compounds such as coffee. The current study attempted to test the anti-cancerous effect of green coffee, medium roasted coffee and decaffeinated coffee in OSCC cell lines and correlate the obtained results with their total phenolic content. We prepared coffee extracts using soxhlet apparatus. Then, we purchased and sub-cultured OSCC-25 cell into four study groups. We subjected three of those groups to coffee extracts separately. We left the remaining group without any treatment as a control group. We assessed cell cytotoxic effect of each extract by MTT viability assay. Additionally, we evaluated the apoptotic effect of each extract on OSCC- 25 cell lines using flowcytometric analysis. Finally, we measured the total phenolic content in each coffee extract. The results revealed that coffee extracts induced varying degrees of cell cytotoxicity and apoptosis. Green coffee showed the highest cytotoxic and apoptotic effect followed by medium roasted coffee, then decaffeinated coffee. The total percentage of necrotic cells were higher in the coffee extracts groups, compared to the control group with a higher value in favor of green coffee followed by medium roasted coffee. Upon chemical analysis, the results showed that green coffee extract contained the highest concentration of phenolic compounds followed by medium roasted coffee then decaffeinated coffee extracts. We concluded that green coffee was the most potent anti-cancer extract. It seems plausible that coffee, and particularly green coffee could be for treating of OSCC.
\end{abstract}

Keywords: Apoptosis, Decaffeinated Coffee, Green Coffee, Medium Roasted Coffee, Oral Squamous Cell Carcinoma Cell Lines, Phenolic Compound

\section{Introduction}

Head and Neck Squamous Cell Carcinoma (HNSCC) is regarded as the sixth most prevailing cancer globally. It is still a severe common health issue, affecting more than 500,000 individuals each year ${ }^{1}$. Oral Squamous Cell Carcinoma (OSCC) is a widely known malignant tumor of the head and neck for nearly $90 \%$ of all tumors that affect the oral cavity ${ }^{2}$. To date, the therapeutic procedures for OSCCs have mainly been based on conventional methods such as surgery, chemotherapy, and radiotherapy; however, such therapeutic approaches cause adverse effects $^{3}$. Despite tremendous efforts made for adequate diagnosis and treatment of OSCC, the five-year patient survival rate did not enhance during the past 30 years; it remained stable at nearly $50 \%$ for about $60-80 \%$ of undiagnosed patients. It has been classified as one of the lowest survival rates for malignant diseases. Besides, high numbers of patients experience poor response to treatment as well as high rate of recurrence ${ }^{4}$.

There is an urgent need to develop novel therapeutic strategies for patients with OSCC. Unexpectedly, some anticancer drugs are mainly made from natural ingredients derived from plants such as licorice $\operatorname{root}^{5,6}$. Therefore, it is worthwhile to screen these natural sources due to their potentiality to prevent or treat cancer particularly OSCC. One of the most recently studied natural products for

${ }^{*}$ Author for correspondence

Article Received on: 31.01.2021

Revised on: 01. 04.2021

Accepted on: 20.05.2021 
its anticancer effect was coffee as well as its ingredients. It has been recently brought to research scope due to its promising biological effects and comparatively minor systemic toxicity.

Coffee is one of the most widely consumed beverages with an international consumption estimated of 165.27 million bags during $2019-2020^{7}$. It is a complex beverage that has more than 1,000 diverse phytochemical constituents among them, polyphenols, caffeine, Chlorogenic Acid (CGA), and diterpenes ${ }^{8}$. The concentrations and bioavailability of its constituents depend on the type of coffee bean species, the origin, the drying, brewing as well as roasting methods, in addition to the methods of preparing the drink ${ }^{9}$. Green Coffee Bean (GCB) refers to the unripe or unroasted coffee beans. It contains a chemical mixture of diverse phytoconstituents with variable physical and chemical properties ${ }^{10}$. Interestingly, the coffee bean roasting process results in several changes to the chemical ingredients of $\mathrm{GCBs}^{11}$.

Concerning coffee and cancer risk, some earlier research work indicated that an average daily consumption of $750 \mathrm{~mL}$ of coffee is enough to stop carcinogenesis and slowdown the progress of various kinds of cancer ${ }^{12}$. Several reports documented the inverse relation between coffee consumption and risk of different types of cancer such as hepatocellular carcinoma ${ }^{13}$, melanoma ${ }^{14}$ and endometrial cancer ${ }^{15}$. Moreover, previous studies reported the chemopreventive effects of coffee against many kinds of cancers. Research studies suggested that coffee inhibit cancer via several ways, such as; anti-inflammatory effects, oxidation inhibition and cancer cell death induction. Its chemopreventive features may be due to the presence of several antioxidant compounds e.g., chlorogenic acid, caffeine, diterpenes such as cafestol and kahweol.

To date, there is limited data that defines how coffee may induce an anti-cancer activity and very few studies have investigated the impact of decaffeinated coffee as well as green coffee on OSCC especially at the cellular level ${ }^{6-18}$. Based on this, the current study attempts to investigate and compare the anticancer effect of Green Coffee (GC), Medium Roasted Coffee (MRC) and Decaffeinated Coffee (DC) on OSCC via assessing their effect on cell vitality, cell apoptosis and necrosis. We also aimed to quantify the total phenolic content in each coffee extract and correlate this with their anticancer effect.

\section{Materials}

Streptomycin, penicillin, trypsin, FBS, and DMEM were obtained from Gibco (Invitrogen, Grand Island, NY, USA). Dimethyl sulfoxide (DMSO), 5-diphenyltetrazolium bromide (MTT), 3-(4,5- Dimethyl thiazol-2yl)-2, were bought from Sigma-Aldrich (St. Louis, MO, USA). PI double staining kit and annexin V-FITC were bought from Biovision (California, USA). Coffee powder (GREEN COFFEE, MEDIUM ROASTED COFFEE AND DECAFFINATED COFFEE) was obtained from local Egyptian markets (Abu Auf, Cairo, Egypt). All other materials were of the highest grade commercially available.

\section{Methods}

\subsection{Coffee Extracts Preparation}

One hundred grams of GC, MRC and DC were weighed and soaked separately with $400 \mathrm{~mL}$ of absolute methanol for three days with frequent agitation. After that, we filtered the extracts using Whatmann filter paper as well as Soxhlet apparatus. Then, we re-soaked the residues with fresh absolute methanol twice. We further concentrated the extract filtrates a rotary evaporator (BUCHI Rotary Evaporator R110, Buchi, Flawil, Switzerland) under low pressure, then dried and stored at $4^{0} \mathrm{C}$ for later use. We prepared a stock solution for each extract by adding DMSO to $1 \mathrm{mg} / \mathrm{ml}$ of each extract. Subsequently, we diluted the stock solution to the required concentrations using (Phosphate Buffered Saline) PBS prior to use.

\subsection{Cell Cultures}

OSCC-25 cells (human tongue oral squamous cell carcinoma cells) were purchased from the American Type Culture Collection (ATCC, Manassas, VA) via VACSERA, Cairo, Egypt. All cells were cultured in Dulbecco's Modified Eagle's Medium (DMEM) (Gibco, Grand Island, NY) supplemented with 10\% Fetal Bovine Serum (FBS), penicillin-streptomycin $1 \%$ (v/v) (Gibco, Grand Island, $\mathrm{NY}$ ). The cells were cultured in $5 \% \mathrm{CO}_{2}$ incubator at 37 $\mathrm{C}$ in a humidified atmosphere. The medium was changed regularly and the cells were sub-cultured every 3-4 days.

\subsection{Cell Viability Assay}

OSCC-25 cell lines viability was examined via using MTT reagent (3-(4, 5- dimethylthiazol-2-yl)-2, 5-dipheny ltetrazolium bromide. Cells were cultured in a 24 -well plate at a concentration of $1 \times 106$ cells/well. We added the extracts of GC, MRC and DC with serial dilution $(100 \mu \mathrm{g} / \mathrm{ml}, 10 \mu \mathrm{g} / \mathrm{ml}, 1 \mu \mathrm{g} / \mathrm{ml}, 0.1 \mu \mathrm{g} / \mathrm{ml}$, and $0.01 \mu \mathrm{g} / \mathrm{ml})$. Four untreated wells remained as control. MTT assay was performed $48 \mathrm{~h}$ after treatments. Mixing solution was prepared by mixing $1 \mathrm{ml}$ PBS with $2 \mathrm{mg}$ of MTT (Sigma- 
Aldrich) powder. The culture medium was altered with $150 \mu \mathrm{l}$ fresh media, in addition to $50 \mu \mathrm{l}$ MTT reagent (2 $\mathrm{mg} / \mathrm{ml}$ in PBS); cell-free wells were regarded as blank controls. Cells were incubated at $37^{\circ} \mathrm{C}$ with $\mathrm{CO}_{2}$ at $5 \%$ and a moist atmosphere for $4 \mathrm{~h}$. After that, the MTT solution was removed and $200 \mu \mathrm{l}$ of DMSO were added to every well. The plate was kept at $37^{\circ} \mathrm{C}$ for $30 \mathrm{~min}$ and after that the OD (optical density) of the wells was measured 570 $\mathrm{nm}$ via a microplate reader (Thermo Scientific Multiskan Spectrum, Thermo Fisher Scientific, Inc., Waltham, MA). $\mathrm{IC}_{50}$ values for coffee extracts on OSCC-25 cell lines were interpreted via Graph Pad Prism version 3.00 (GraphPad, San Diego, CA).

\subsection{Annexin-V/PI Dual Staining Assay}

Apoptosis quantitative assessment was carried out via Fluorescein Isothiocyanate (FITC) and Annexin V Apoptosis Detection Kit (BD Biosciences, Waltham, MA). First, cells were cultured at density $\left(1.5 \times 10^{5}\right.$ cells $)$ and the $\mathrm{IC}_{50}$ value of each extract were added and incubated for $72 \mathrm{~h}$. Control group was left without any treatment. After $72 \mathrm{~h}$, cells were collected, washed twice via cold PBS, and re-suspended with binding buffer. One hundred $\mathrm{mL}$ of cells was transferred to a tube and incubated at room temperature with $5 \mathrm{~mL}$ of propidium iodide (PI) as well as $5 \mathrm{~mL}$ of FITC-conjugated Annexin V (Annexin V-FITC) for 15 minutes in dark room. The stained cells were diluted with binding buffer and analyzed with a flow cytometer (Becton Dickinson FACSCanto II (BD FACSCanto II, BD Biosciences, Waltham, MA).

\subsection{Total Phenolic Acid Measurements}

Gallic acid stock solution of $1 \mathrm{mg} / \mathrm{ml}$ in methanol was prepared, and 7 serial dilutions were prepared in the concentrations of $500,250,125,62.5,31.2,15.6$, and $7.8 \mu \mathrm{g} / \mathrm{ml}$. Solutions of sample labeled GC, MRC and DC were prepared in concentration of $3 \mathrm{mg} / \mathrm{ml}$ in water. The results were recorded using: gallic acid standards and coffee sample. Each of the 7 standards and the sample were pipetted in the plate wells in 6 replicates. Measurement was performed at $765 \mathrm{~nm}$ using Hitachi ratio beam spectrophotometer. It is measured as Gallic Acid equivalents GAE/g of dry plant material according to the regression curve expressed in $\mu \mathrm{g}$ of gallic acid equivalent/mg of dry extract.

\section{Statistical Analysis}

Data was encoded and processed via SPSS version 25. Microsoft Excel sheets were employed for data manipulation as well as for making the graphic presentation. Quantitative variables were presented as Mean and Standard Deviation. Comparisons between treated groups and control groups was done by one-way analysis of variance (ANOVA), and then followed by post hoc Tukey's test. P-value was considered as follows: $\mathrm{P}$-value $>0.05$, not significant, $\mathrm{P}$ value $\leq 0.05$, significant, $P$ value $\leq 0.001$, highly significant.

\section{Results}

\subsection{Cell Viability and IC 50 Values}

The results showed that coffee extracts induce cell cytotoxicity which is directly proportional to coffee concentration. GC showed the highest cytotoxic effect followed by MRC, then DC. Table 1 represents the mean $\mathrm{IC}_{50}$ values for each coffee extract.

Table 1. $I C_{50}$ values for $G C, M R C$ and $D C$

\begin{tabular}{|c|c|}
\hline Experimental groups & IC $5 \mathbf{0 ~} \mathbf{~ g} / \mathbf{m l}$ \\
\hline Green coffee & $17.1 \pm 0.69$ \\
\hline Medium Roasted Coffee & $57.95 \pm 2.28$ \\
\hline Decaffeinated Coffee & $103.32 \pm 4.52$ \\
\hline
\end{tabular}

\subsection{Assessment of Apoptosis using Annexin-V FITC/PI Dual Staining Flow Cytometry Assay}

Flowcytometric analysis indicated a remarkable reduction in the percentage of viable cells when exposed to coffee extracts compared to control group. The overall percentage of early and late apoptotic cells as well as necrotic cells showed high significant values in all study groups compared to control. The results are represented in Table 2, in a stacked column chart (Figure 1) and in Figure 2 (a, b, c and d).

When the average values for each incident were compared, the GC and MRC extracts showed a reduction in the proportion of viable cells as well as a significant increase in early and late apoptotic cell subpopulations more than the control group $(\mathrm{p}<0.001)$. Likewise, the effect of DC extracts on OSCC-25 cells resulted in a statistically remarkable increase in early apoptotic cell subpopulation $(\mathrm{P}<0.021)$ and late apoptotic cell subpopulations $(\mathrm{p}<0.016)$ compared to control group. Furthermore, there was no significance difference in the percentage of necrotic cells between MRC and GC (P $<0.106)$. 
Table 1. Average percentage of apoptotic and necrotic cells in OSCC-25 cell cultures incubated with GC, MRC and DC compared to control group.

\begin{tabular}{|c|c|c|c|c|c|c|}
\hline & & $\begin{array}{l}\text { Negative } \\
\text { Control }\end{array}$ & GC & MRC & DC & P Value \\
\hline $\begin{array}{c}\text { Total apoptotic } \\
\text { cells }\end{array}$ & \multirow{4}{*}{ Mean $\% \pm S D$} & $1.62 \pm 0.09$ & $17.99 \pm 1.33$ & $7.55 \pm 0.91$ & $4.74 \pm 0.48$ & $<0.001^{* *}$ \\
\hline $\begin{array}{l}\text { Early apoptotic } \\
\text { cells }\end{array}$ & & $0.91 \pm 0.03$ & $7.92 \pm 0.52$ & $2.44 \pm 0.35$ & $1.94 \pm 0.13$ & $<0.001^{* *}$ \\
\hline $\begin{array}{l}\text { Late apoptotic } \\
\text { cells }\end{array}$ & & $0.33 \pm 0.04$ & $8.26 \pm 0.52$ & $3.66 \pm 0.49$ & $1.84 \pm 0.41$ & $<0.001^{* *}$ \\
\hline Necrotic cells & & $0.37 \pm 0.05$ & $2.18 \pm 0.22$ & $1.83 \pm 0.18$ & $1.14 \pm 0.22$ & $<0.001^{* *}$ \\
\hline
\end{tabular}

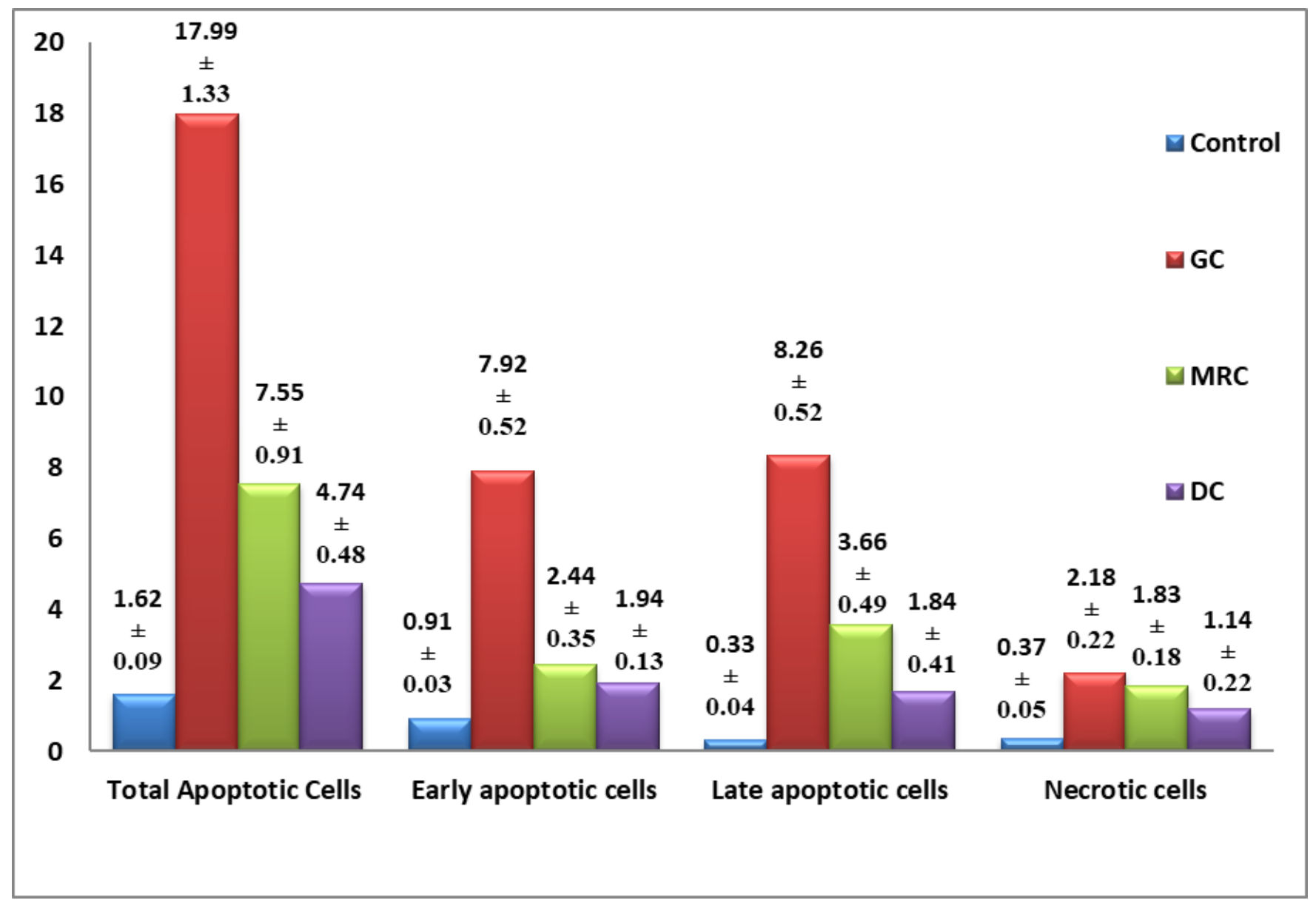

Figure 1. A stacked column chart demonstrating the ratio of necrotic as well as apoptotic cells in the studied experimental groups versus the control group. Data are presented as the mean \pm standard deviation of the mean. ${ }^{* *} \mathrm{P}<0.001$, flow cytometry. 


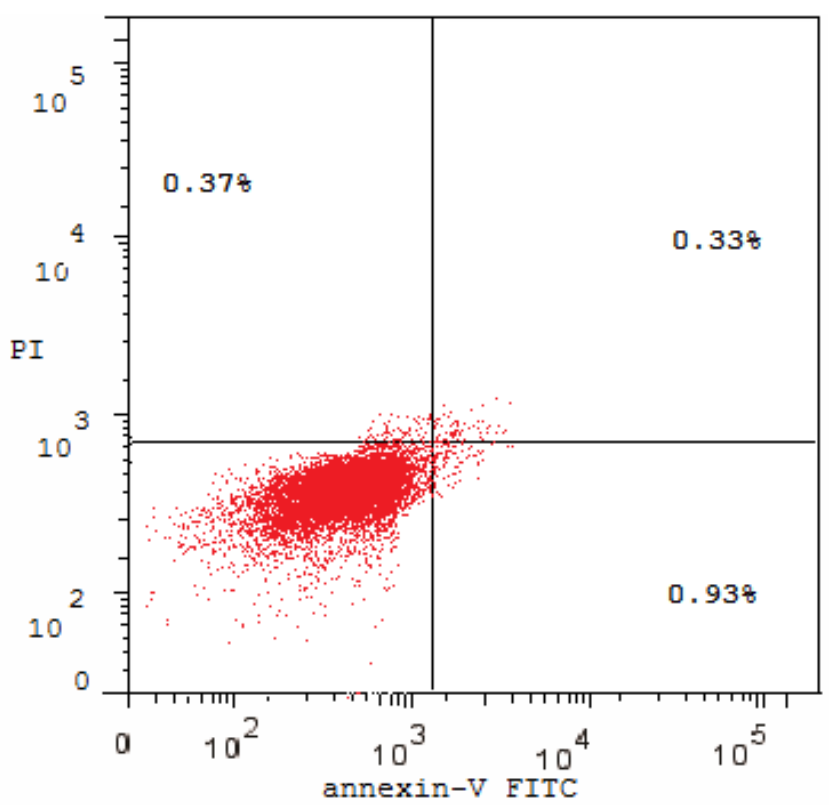

Figure 2a

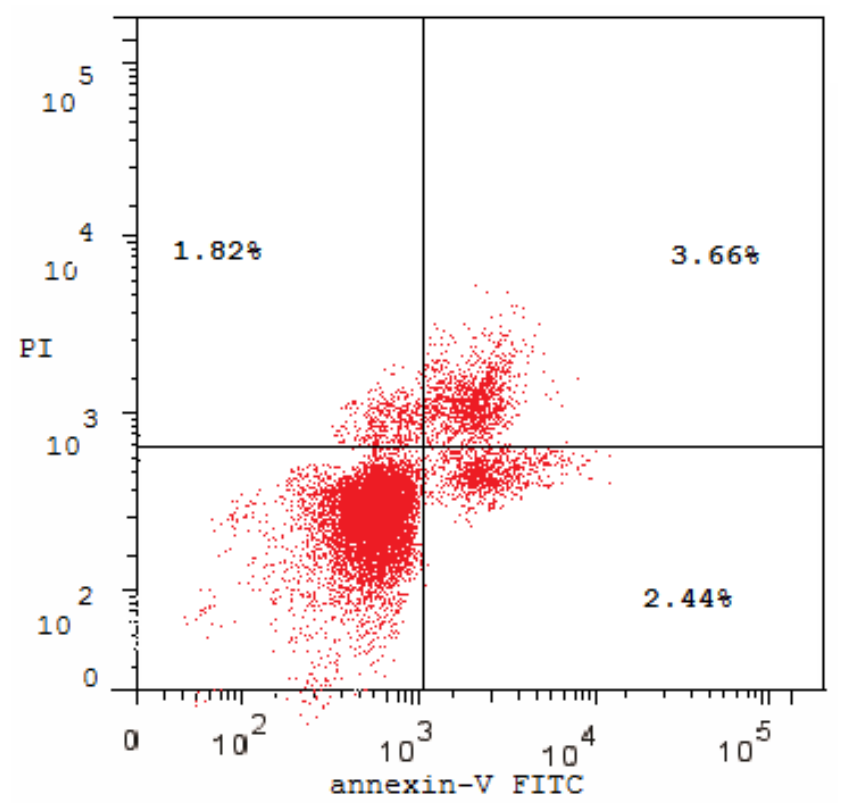

Figure 2c

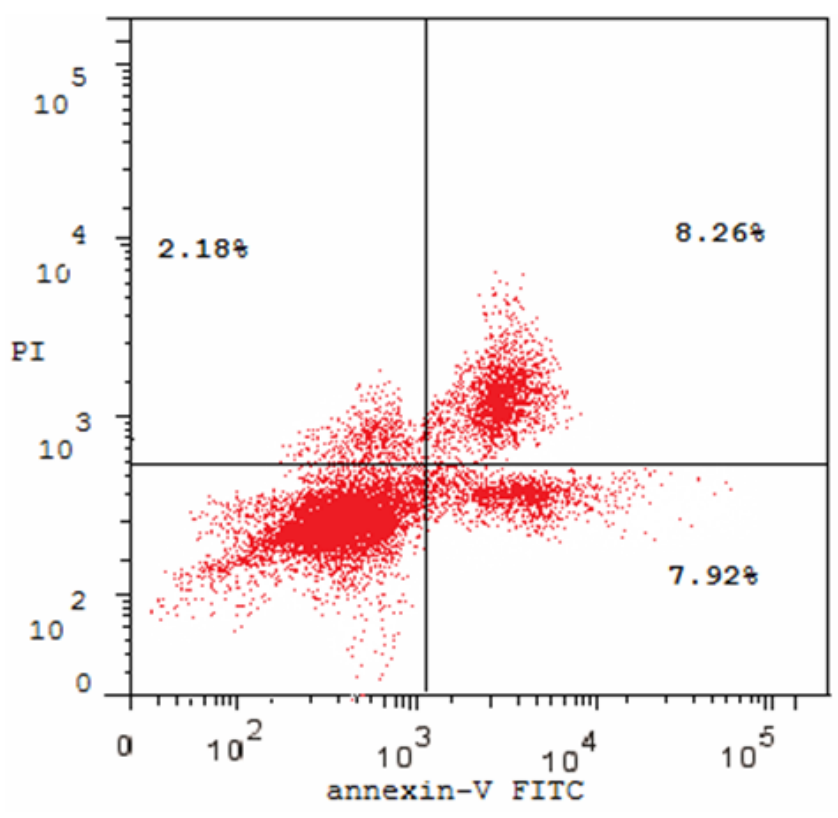

Figure 2b

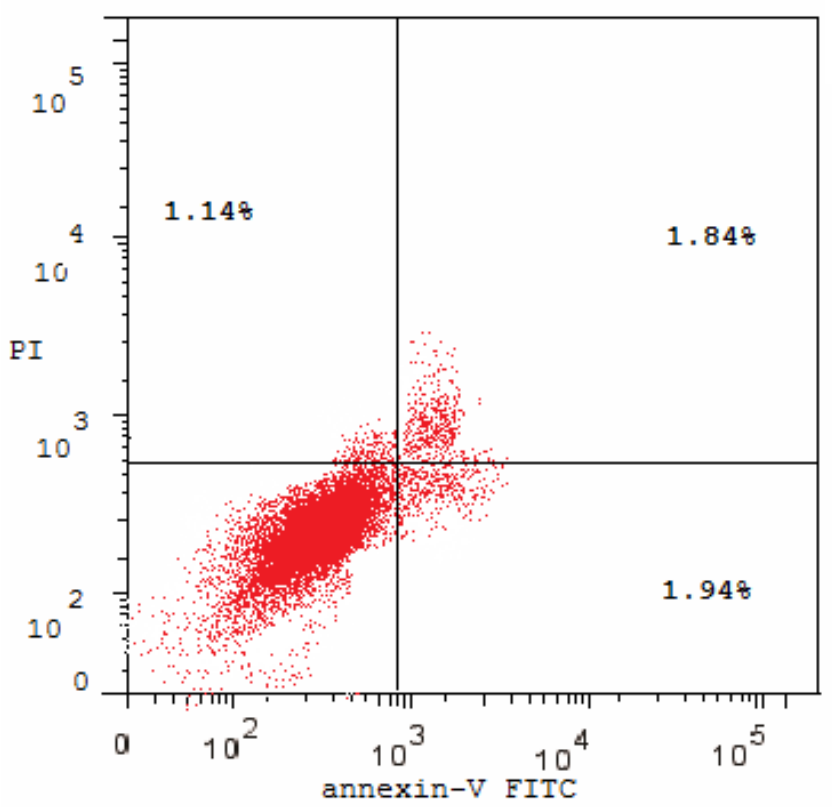

Figure 2d

Figure 2. Annexin V/PI dual-staining assay of OSCC-25 cells treated with coffee extracts after $72 \mathrm{~h}$ for control (2a), GC (2b), MRC (2c) and DC (2d) groups. The Y axis stands for the group labeled PI, while the X axis stands for the Annexin V labeled FITC positive cells. The lower part of the dot plot towards the left represents viable cells, while lower part of towards the right stands for the early apoptotic cells. The upper part of the dot plot towards the right demonstrates the late apoptotic cells whereas the upper part towards the left represents necrotic cells.

\subsection{Total Phenolics Measurement}

It was clearly observed that all samples had a plausible number of phenolic compounds. Nonetheless, the overall phenolic compounds in GC extract were remarkably ( $\mathrm{p} \leq$ 0.05) higher compared to MRC and DC. Total phenolic compounds 247.8889 $\pm 0.03 \mathrm{mg} / \mathrm{g}$ (GAE/g DW), $222.75 \pm 0.04 \mathrm{mg} / \mathrm{g}(\mathrm{GAE} / \mathrm{g} \mathrm{DW})$ and $157.63 \pm 0.01 \mathrm{mg} / \mathrm{g}$ (GAE/g DW) were found in GC, MRC and DC extracts, respectively. Variance analysis demonstrated that there is a marked $(p \leq 0.05)$ difference between the total phenolic in the GC as well as MRC extracts. 


\section{Discussion}

OSCC represents $90 \%$ of oral cancers and according to the latest WHO data in 2017; it is responsible for about $0.23 \%$ of total deaths in Egypt ${ }^{19}$. Despite complex diagnostic modalities, most cases are diagnosed at late stages with a poor prognosis and a low survival rate about $50 \%{ }^{20}$. Surgery, radiotherapy, and/or chemotherapy, remain the main strategies for managing OSCC $^{21}$. However, their adverse side effects encouraged the researchers to find new therapeutic approaches with limited side effects, improved anti-carcinogenic and chemo-preventive properties.

Coffee is a widely consumed natural beverage that is prepared in several different ways, and the roasted form is the most consumed drink due to its special aroma and tasty flavor ${ }^{22}$. Recently, GC consumption has become more prevalent as a primarily nutritional aid to lose weight ${ }^{23}$. Nevertheless, several studies on the antioxidant activity of RC have reported controversial results. In addition, the antioxidant activity of GC as well as DC needs further investigation specifically in oral cancer ${ }^{24,25}$. That's why we conducted our study.

Firstly, the MTT assay was conducted in order to investigate the impact of various coffee extracts on the viability of OSCC- 25 cell lines. The findings showed a marked dose-dependent reduction in viability of OSCC25 cell lines with significant differences between all groups studied. GC extract showed a significant decrease in cell viability at the lowest concentration followed by MRC. This can be attributed to the high total phenolic and CGAs content present in GC extract. The lowest cell viability indicated the highest cytotoxic potentiality of the extract. This finding is consistent with the findings of Rao and Nadumane, 2016 that reported that GC had a potent cytotoxic effect against ovarian and cervical cancer cell lines ${ }^{26}$.

In contrast, Mojica et al., 2018 found that GC had a less cytotoxic effect against OSCC cell lines compared to light and medium roasted coffee. They reported that even with therapeutic methods that depend on a high concentration of coffee extracts, the cell viability of normal cells was slightly affected compared to cancer cell lines ${ }^{17}$. Moreover, Cho et al., 2014 found that lightly roasted coffee offers the greatest antioxidant activity compared to larger roasted coffee as well as unroasted coffee ${ }^{27}$. This cytotoxic capability of MRC is due to the concentrated caffeine exceeding its $\mathrm{GC}$ value as determined by chemical analysis of coffee extracts. It may also be due to the formation of phenolic as well as melanoidins throughout the roasting process, preventing oxidative damage to cells ${ }^{28}$.

DC exhibited the least cytotoxic effect on OSCC-25 cell lines which can be related to its reduced bioactive compounds and caffeine deficiency as well as CGAs which was confirmed by chemical analysis. The substantial cytotoxic effect of DC may be induced by the residual phenolic content or it may be due to other compounds formed during the roasting of decaffeinated GC beans such as melanoidins that have significant antioxidant activity $^{29}$.

As a main objective of cancer therapy, apoptotic potentiality induced by GC, MRC \&DC extracts in OSCC25 cell lines were studied using the Annexin V-FITC/PI assay to differentiate between necrotic and apoptotic cell death. Negative control cells exhibited negative staining of live cells Annexin-V while GC, MRC as well as DC-treated OSCC-25 cell lines indicated positive staining of both Annexin-V and Annexin-V/PI indicating early as well as late apoptosis, respectively. GC, MRC and DC decreased OSCC- 25 cell viability and increased the percentage of total apoptotic cells after $72 \mathrm{~h}$ of incubation. Moreover, there was a marked increase in necrotic cell death than in unexposed cells.

GC treated cell lines showed the largest proportion of overall apoptotic and necrotic cells followed by MRC, then DC. The percentage of total apoptosis was more significant than necrotic cells among all groups studied. Interestingly, both GC and MRC groups showed a higher percentage of late apoptotic than early apoptotic cells while DC showed reverse results. These results can be attributed to the high overall concentrations of phenolic compounds in the GC as well as in MRC which have been reported to have a regulatory role in cancer cell apoptosis and autophagy via the production of ROS that activates intrinsic pathway by disrupting mitochondrial membrane integrity in addition to regulation of autophagy ${ }^{30,31}$.

Among coffee phenolic compounds, CGA has the highest concentration in GC group and is associated with the highest percentage of necrotic and apoptotic cells. Wang et al., 2019 investigated the anti-cancer effect of CGA and reported that CGAs have the ability to induce apoptotic cell death as well as inhibit cell proliferation ${ }^{32}$. CGAs have been reported to trigger apoptosis via inducing hydrogen peroxide production, stimulation of several caspases mainly caspase-3, besides activating mitochondria-dependent pathways ${ }^{33,34}$. Furthermore, caffeine may contribute to the induction of apoptosis in various cancer cell lines via several pathways ${ }^{35,36}$. It can inhibit cell proliferation and induce cell apoptosis by activating the caspase-9/caspase-3 pathway ${ }^{37}$.

Based on these data, we suggested that phenolic compounds and caffeine significantly contribute to the potential of coffee extracts as the GC which has the highest phenolic content, CGA as well as considerable 
amount of caffeine, showed the highest percentage of total apoptosis. In the same context, MRC with lower phenolic content and CGAs than GC, however it has the highest caffeine content, after GC regarding the total percentage of apoptotic cells. This means that the phenolic compounds including CGAs are more effective in inducing cell apoptosis than caffeine. This is also supported by ability of DC to induce apoptosis and necrosis despite deficiency of caffeine and CGA.

After quantifying total phenolic (GAE in the extracts of GC, MRC and DC), the current data revealed that GC has highest amount of total phenolic followed by MRC then DC which is compatible with the findings reported by Mojica et al. ${ }^{17}$. They demonstrated that GC has higher total phenolic and CGAs than MRC, and thus promotes more cytotoxic effect.

With regard to DC, our results showed lower content of phenolic compounds. To date, there have been limited studies assessed the impact of decaffeination process on the chemical composition of coffee. Decaffeination process is known to occur before roasting, besides it is often made by organic solvent extraction method. Moreover, using water as a solvent during the decaffeination process might lead to a loss of CGA and related compounds ${ }^{38}$.

By combining knowledge of anticancer assays in this study, it can be demonstrated that the anticancer effect of coffee extracts could be related to its phenolic content. This means that total amount of phenolic content is valuable for predicting the anticancer effect of coffee as GC contains a large number of phenolic compounds which exert their anticancer effect on OSCC- 25 cell lines. Several other components which were proved to have a potent anticancer effect on several types of cancer, such as; cafestol, kahweol, tocopherols and trigonelline may contribute to the anticancer effect of DC in this study ${ }^{39}$.

Furthermore, the present study also supports the cytotoxicity hypothesis of coffee against OSCC cell lines. The study indicates that coffee has anticancer effect on OSCC through induction of cellular cytotoxicity, and apoptosis. The findings of the current study are consistent with the current results that several epidemiological evidences indicate a decreased risk of developing cancer induced by coffee intake ${ }^{40}$. Many clinical studies proved that caffeinated coffee beverages are associated with lower risk of cancer, unlike decaffeinated coffee, which is consistent with our results which showed decreased anticancer effect in DC groups ${ }^{41}$.
In this study, the anticancer capacity observed in GC followed by MRC, while DC has the least anticancer effect. We also observed that GC has the highest total phenolic compounds which have been reported to be characterized by a potent antioxidant capacity both in vivo and in vitro ${ }^{42}$. The potent inhibitory action of phenolic compounds inhibits the mechanism of carcinogenesis.

Overall, based on our data and previous research works, our study underlined that it is obvious that the coffee especially GC has a primary anticancer effect against OSCC making it a promising chemo-preventive and chemotherapeutic agent for oral cancer treatment.

\section{Conclusion}

Coffee has anticancer effects and it interferes with carcinogenesis in different ways as it negatively affects cell viability. It also results in induction of cell apoptosis and necrosis. GC has the most potent anticancer activity among all the studied coffee extracts because of the high content of bioactive antioxidant compounds. We observed that coffee roasting reduces the total phenolic amount. The decaffeination of coffee also reduces the percentage of total phenolic compounds which significantly weaken the anticancer action of coffee. The findings of this study provide some useful data about developing effective prevention techniques as well as novel therapeutic regimens to enhance human health.

\section{Funding}

This research did not receive any specific grant from funding agencies in the public, commercial, or not-forprofit sectors.

\section{Conflict of Interest}

Nothing was declared.

\section{References}

1. Tsompana M, Gluck C, Sethi I, Joshi I, Bard J, Nowak NJ, Sinha S, Buck MJ. Reactivation of super-enhancers by KLF4 in human head and neck squamous cell carcinoma. Oncogene. 2020; 39(2):262-77. https:// doi.org/10.1038/s41388-019-0990-4. PMid:31477832

2. Bray F, Ferlay J, Soerjomataram I, Siegel RL, Torre LA, Jemal A. Global cancer statistics 2018: GLOBOCAN estimates of incidence and mortality worldwide for 
36 cancers in 185 countries. CA. 2018; 68(6):394-424. https://doi.org/10.3322/caac.21492. PMid:30207593

3. Colevas AD, Yom SS, Pfister DG, Spencer S, Adelstein D, Adkins D, et al. NCCN guidelines insights: Head and neck cancers, version 1. J Natl Compr Cancer Netw. 2018; 16(5):479-90. https://doi.org/10.6004/ jnccn.2018.0026. PMid:29752322

4. Thomson PJ. Perspectives on oral squamous cell carcinoma prevention-proliferation, position, progr ession and prediction. J Oral Pathol Med. 2018; 47(9):803-7. https://doi.org/10.1111/jop.12733. PM id:29752860

5. Newman DJ, Cragg GM. Natural products as sources of new drugs from 1981 to 2014. J Nat Prod. 2016; 79(3):629-61. https://doi.org/10.1021/acs. jnatprod.5b01055. PMid:26852623

6. Wang J, Zhang YS, Thakur K, Hussain SS, Zhang JG, Xiao GR, et al. Licochalcone A from licorice root, an inhibitor of human hepatoma cell growth via induction of cell apoptosis and cell cycle arrest. Food Chem Toxicol. 2018; 120:407-17. https://doi. org/10.1016/j.fct.2018.07.044. PMid:30055311

7. Baeza G, Sarriá B, Bravo L, Mateos R. Polyphenol content, in vitro bioaccessibility and antioxidant capacity of widely consumed beverages. J Sci Food Agr. 2018; 98(4):1397-406. https://doi.org/10.1002/ jsfa.8607, PMid:28771735

8. Semen S, Mercan S, Yayla M, Açikkol M. Elemental composition of green coffee and its contribution to dietary intake. Food Chem. 2017; 215:92-100. https://doi.org/10.1016/j.foodchem.2016.07.176. PMid:27542454

9. Uman E, Colonna-Dashwood M, Colonna-Dashwood L, Perger M, Klatt C, Leighton S, et al. The effect of bean origin and temperature on grinding roasted coffee. Sci Rep. 2016; 6. https://doi.org/10.1038/ srep24483. PMid:27086837. PMCid:PMC4834475

10. de Melo Pereira GV, de Carvalho Neto DP, Júnior AI, do Prado FG, Pagnoncelli MG, Karp SG, Soccol CR. Chemical composition and health properties of coffee and coffee by-products. Adv Food Nutr Res. 2020; 91:65-96. https://doi.org/10.1016/bs.afnr. 2019.10.002. PMid:32035601

11. Esposito F, Fasano E, De Vivo A, Velotto S, Sarghini F, Cirillo T. Processing effects on acrylamide content in roasted coffee production. Food Chem. 2020. https://doi.org/10.1016/j.foodchem.2020.126550. PMid:32169765
12. Bakuradze T, Lang R, Hofmann T, Eisenbrand G, Schipp D, Galan J, et al. Consumption of a dark roast coffee decreases the level of spontaneous DNA strand breaks: a randomized controlled trial. Eur J Nutr. 2015; 54(1):149-56. https://doi.org/10.1007/s00394014-0696-x. PMid:24740588

13. Bravi F, Tavani A, Bosetti C, Boffetta P, La Vecchia C. Coffee and the risk of hepatocellular carcinoma and chronic liver disease: A systematic review and meta-analysis of prospective studies. Eur J Cancer Prev. 2017; 26(5):368-77. https://doi.org/10.1097/ CEJ.0000000000000252 PMid:27111112.

14. Micek A, Godos J, Lafranconi A, Marranzano M, Pajak A. Caffeinated and decaffeinated coffee consumption and melanoma risk: A dose-response meta-analysis of prospective cohort studies. Int J Food Sci Nutr. 2018; 69(4):417-26. https://doi.org/10.1080/0963748 6.2017.1373752. PMid:2889136

15. Lukic M, Guha N, Licaj I, van den Brandt PA, Stayner LT, Tavani A, et al. Coffee drinking and the risk of endometrial cancer: an updated meta-analysis of observational studies. Nutr Cancer. 2018; 70(4):51328. https://doi.org/10.1080/01635581.2018.1460681. PMid:29708405

16. Miller EG, Gonzales-Sanders AP, Couvillon AM, Wright JM, Hasegawa S, Lam LKT, et al. Inhibition of oral carcinogenesis by green coffee beans and limonoid glucosides. In: Wang, M, Osawa T, Ho CT, Rosen RT, editors. Food Phytochemicals for Cancer Prevention I. Fruits and Vegetables. Washington: ACS Symposium Series 546; 1994. https://doi.org/10.1021/ bk-1994-0546.ch017

17. Mojica BE, Fong LE, Biju D, Muharram A, Davis IM, Vela KO, et al. The impact of the roast levels of coffee extracts on their potential anticancer activities. J Food Sci. 2018; 83(4):1125-30. https:// doi.org/10.1111/1750-3841.14102. PMid:29577313

18. Monente C, Ludwig IA, Irigoyen A, De Peña MP, Cid C. Assessment of total (free and bound) phenolic compounds in spent coffee extracts. J Agric Food Chem. 2015; 63(17):4327-34. https://doi. org/10.1021/acs.jafc.5b01619. PMid:25891228

19. Hassabou NF, Farag AF. Anticancer effects induced by artichoke extract in oral squamous carcinoma cell lines. J Egypt Natl Canc Inst. 2020; 32:1-10. https://doi. org/10.1186/s43046-020-00026-4. PMid:32372389

20. Sinevici N, O'sullivan J. Oral cancer: deregulated molecular events and their use as biomarkers. Oral 
Oncology. 2016; 61:12-18. https://doi.org/10.1016/j. oraloncology.2016.07.013. PMid:27688099

21. Kjær I, Lindsted T, Fröhlich C, Olsen JV, Horak ID, Kragh M, Pedersen MW. Cetuximab resistance in squamous carcinomas of the upper aerodigestive tract is driven by receptor tyrosine kinase plasticity: Potential for mAb mixtures. Mol Cancer Ther. 2016; 15(7):1614-26. https://doi.org/10.1158/1535-7163. MCT-15-0565. PMid:27196767

22. Alves RC, Rodrigues F, Nunes MA, Vinha AF, Oliveira MBP. State of the art in coffee processing by-products, In Handbook of coffee processing by-products, 1 st ed, p 1-26, Academic Press, London, UK; 2017. https:// doi.org/10.1016/B978-0-12-811290-8.00001-3

23. Farias-Pereira R, Oshiro J, Kim KH, Park Y. Green coffee bean extract and 5-O-caffeoylquinic acid regulate fat metabolism in Caenorhabditis elegans. J Funct Foods. 2018; 48:586-93. https://doi. org/10.1016/j.jff.2018.07.049

24. Rodrigues NP, Bragagnolo N. Identification and quantification of bioactive compounds in coffee brews by HPLC-DAD-MSn. J Food Compos Anal. 2013; 32(2):105-15. https://doi.org/10.1016/j.jfca.2013.09.002

25. Caporaso N, Genovese A, Canela MD, Civitella A, Sacchi R. Neapolitan coffee brew chemical analysis in comparison to espresso, moka and American brews. Food Research International, 2014; 61:152-60. https://doi.org/10.1016/j.foodres.2014.01.020

26. Rao S, Nadumane VK. Evaluation of the anticancer potential of coffee beans: An in vitro study. Indian Journal of Traditional Knowledge. 2016; 15(2):26671.

27. Cho AR, Park KW, Kim KM, Kim SY, Han J. Influence of Roasting Conditions on the Antioxidant Characteristics of C olombian Coffee (C offea arabica L.) Beans. Journal of food biochemistry. 2014; 38(3):271-80. https://doi.org/10.1111/jfbc.12045

28. Simões J, Moreira ASP, Passos CP, Nunes FM, Domingues MRM, Coimbra MA. Polysaccharides and Other Carbohydrates. In: Coffee, Chapter 19. London, United Kingdom: Royal Society of Chemistry; 2019. https://doi.org/10.1039/9781782622437-00445. PMCid:PMC6843862

29. Moreira ASP, Nunes FM, Domingues MR, Coimbra MA. Coffee melanoidins: Structures, mechanisms of formation and potential health impacts. Food Funct. 2012; 3(9): 903-15. https://doi.org/10.1039/ c2fo30048f. PMid:22584883
30. Lewandowska H, Kalinowska M, Lewandowski W, Stepkowski TM, Brzoska K. The role of natural polyphenols in cell signaling and cytoprotection against cancer development. J Nutr Biochem. 2016; 32:1-19. https://doi.org/10.1016/j.jnutbio.2015.11.006. PMid:27142731

31. Zhao C, Sakaguchi T, Fujita K, Ito H, Nishida N, Nagatomo A, et al. Pomegranate-derived polyphenols reduce reactive oxygen species production via SIRT3-mediated SOD2 activation. Oxid Med Cell Longev. 2016. https://doi.org/10.1155/2016/2927131. PMid:27840668. PMCid:PMC50932

32. Wang X, Liu J, Xie Z, Rao J, Xu G, Huang K, et al. Chlorogenic acid inhibits proliferation and induces apoptosis in A498 human kidney cancer cells via inactivating PI 3K/Akt/mTOR signalling pathway. J Pharm Pharmacol. 2019; 71(7):1100-9. https://doi. org/10.1111/jphp.13095. PMid:30989669

33. Cho Y-H, Bahuguna A, Kim H-H, Kim D, Kim H-J, Yu $\mathrm{J}-\mathrm{M}$, et al. Potential effect of compounds isolated from Coffea arabica against UV-B induced skin damage by protecting fibroblast cells. Journal of Photochemistry and Photobiology B: Biology. 2017; 174:323-32. https://doi.org/10.1016/j.jphotobiol.2017.08.015. PMid:28818778

34. Hu GL, Wang X, Zhang L, Qiu MH. The sources and mechanisms of bioactive ingredients in coffee. Food Funct. 2019; 10(6):3113-26. https://doi.org/10.1039/ C9FO00288J. PMid:31166336

35. Miwa S, Sugimoto N, Yamamoto N, Shirai T, Nishida $\mathrm{H}$, Hayashi K, et al. Caffeine induces apoptosis of osteosarcoma cells by inhibiting AKT/mTOR/S6K, NF-?B and MAPK pathways. Anticancer research. 2012; 32(9):3643-9.

36. Saiki S, Sasazawa Y, Imamichi Y, Kawajiri S, Fujimaki T, Tanida I, et al. Caffeine induces apoptosis by enhancement of autophagy via PI3K/ Akt/mTOR/p70S6K inhibition. Autophagy. 2011; 7(2):176-87. https://doi.org/10.4161/auto.7.2.14074. PMid:21081844. PMCid:PMC3039768

37. Liu H, Zhou Y, Tang L. Caffeine induces sustained apoptosis of human gastric cancer cells by activating the caspase $9 /$ caspase 3 signalling pathway. Mol Med Rep. 2017; 16(3):2445-54. https://doi. org/10.3892/mmr.2017.6894. PMid:28677810. PMC id:PMC5547974

38. Rebai O, Amri M. Chlorogenic Acid Prevents AMPA-Mediated Excitotoxicity in Optic Nerve Oligodendrocytes Through a PKC and Caspase- 
Dependent Pathways. Neurotoxicity Research. 2018; 34(3): 559-73. https://doi.org/10.1007/s12640-0189911-5. PMid:30006682

39. Krstic M, Stojadinovic M, Smiljanic K, StanicVucinic D, Velickovic TC. The anti-cancer activity of green tea, coffee and cocoa extracts on human cervical adenocarcinoma HeLa cells depends on both pro-oxidant and anti-proliferative activities of polyphenols. RSC Adv. 2015; 5(5):3260-8. https:// doi.org/10.1039/C4RA13230K

40. Micek A, Godos J, Lafranconi A, Marranzano M, Pajak A. Caffeinated and decaffeinated coffee consumption and melanoma risk: A dose-response meta-analysis of prospective cohort studies. Int. J. Food Sci. Nutr.
2018; 69(4):417-26. https://doi.org/10.1080/0963748 6.2017.1373752. PMid:28891369

41. Lodise O, Patil,K, Karshenboym I, Prombo S, Chukwueke C, Pai SB. Inhibition of prostate cancer cells by 4, 5-dicaffeoylquinic acid through cell cycle arrest. Prostate Cancer. 2019:1-8. https://doi. org/10.1155/2019/4520645. PMid:31263600. PMC id:PMC6556292

42. Cho Y-H, Bahuguna A, Kim H-H, Kim D, Kim H-J, Yu $\mathrm{J}-\mathrm{M}$, et al. Potential effect of compounds isolated from Coffea arabica against UV-B induced skin damage by protecting fibroblast cells. J Photochem Photobiol B. 2017; 174:323-32. https://doi.org/10.1016/j. jphotobiol.2017.08.015. PMid:28818778 